\title{
A novel inter-story drift limit proposal for TBEC2018 and fragility prognosis with TSC2007
}

\author{
Onur Onat ${ }^{* 1}$ (iD), Burak Yön ${ }^{2}$ (D) \\ ${ }^{1}$ Inonu University, Department of Civil Engineering, Malatya, Turkey \\ ${ }^{2}$ Munzur University, Department of Civil Engineering, Tunceli, Turkey
}

\begin{abstract}
The basic purpose of this paper is to investigate and propose a novel inter-story drift limits for the current Turkish Seismic Code to get easy structural assessment by using software. For this aim, numerical analysis was performed by modeling two types of RC frame structures. One of them is 5 stories, the other of them is 7 stories. Two different concrete classes, C20 and C25, were considered and three tension reinforcement ratios were considered for analysis. Tension reinforcement ratios were determined by half of the compressive reinforcement, equal to compressive reinforcement and double the compressive reinforcement ratio. Incremental dynamic analyses (IDA) were performed on these buildings. In this study to execute IDA, eleven seismic acceleration benchmark records were multiplied with various scaling factors from 0.2 to 1.0. Maximum base shear and corresponding roof displacement responses obtained from IDA curves were generated according to these responses. IDA curves were compared with each other by deriving fragility graphs. According to results, proposed limits for the current Turkish seismic code (TBEC-2018) provide, $0.6 \%, 2.4 \%$ and $3.3 \%$ respectively for $\mathrm{MN}, \mathrm{GV}$ and $\mathrm{GC}$, rather safe limits compared to drift limits presented in the foredate seismic code (TSC-2007).
\end{abstract}

\section{Keywords}

Seismic code; Drift limits; Fragility curves; Numerical assessment; Reinforced concrete structures

Received: 26 February 2021; Accepted: 24 April 2021

ISSN: 2630-5763 (online) C 2021 Golden Light Publishing All rights reserved.

\section{Introduction}

The countries, under high seismic risk and where the structural stock needs to be assessed fast and in a correct manner before or after an earthquake, seek to utilize a quick procedure during a numerical analysis [1]. Because structural systems are moderately or severely damaged following an earthquake, as experienced in recent decades [2-8]. Drift limits and deriving fragility curves are the prominent methods in recent decades to assess a structural system. Because these two concepts are

* Corresponding author

Email: onur.onat@inonu.edu.tr integrated into each other. These two important issues were presented in detail under related subsections.

\subsection{Drift limits}

Damage or drift limits are of vital importance to assess an available condition of structural system to determine serviceability after a seismic action as presented previously [1]. For instance, these drift limits were utilized at three levels in fore date Turkish Seismic Code (TSC-2007) [9]. These are $1 \%, 3 \%$ and $4 \%$ for Minimum Damage Limits 
(MN), Heavy Damage (GV) and Collapse Limit (GC), respectively. However, in the current seismic code (TBEC-2018) there are not available any interstory drift limits for structural systems. On this point of view, limited study is available on the basis of the basic design philosophy of Turkish Building Seismic Code 2018 (TBEC2018) [10]. A few literature studies related to TBEC2018 are listed. For instance, TSC 2007, TBEC2018 and ASCE716 were compared to each other in terms of base shear force, top displacement, period of structure and relative story displacement on mid-rise reinforced concrete structures by using nonlinear dynamic analysis [11]. Doğan et al. produced a total of 12 reinforced concrete columns full scale with square cross sections were tested under earthquake resembling reversible cycling lateral load and axial force. To simulate the existing building stock before the millennium, reinforced concrete columns which are non-complying with the code have been produced. The basic purpose is their study is to record load and displacement level with 390 images were captured to classify parameters such as total cracks area, total cracks length, maximum crack length and maximum crack width to process the amount of damage on the column through the feature extraction process of the cracks in the images and to determine certain damage limits by using digital images [1] are depicted in Fig. 1.

On a global scale, the drift limit studies were performed in nearly the same manner by performing experimental study or numerical assessment. For instance, Surana performed a series of nonlinear analyses on mid-rise and high-rise structural systems to determine interstory limits.

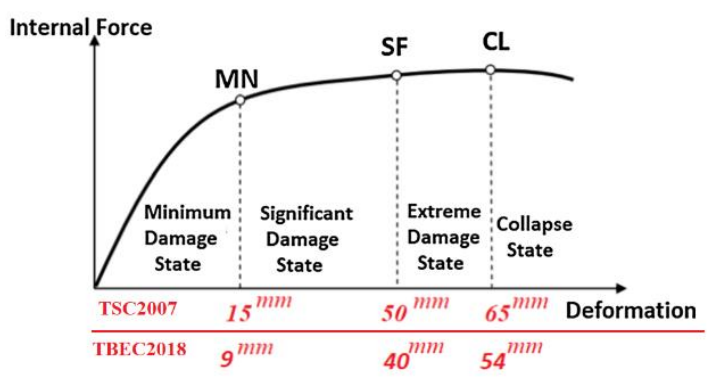

Fig. 1. Damage limits for images [1]
After analyses, $0.33 \%, 0.67 \%, 2.00 \%$ and $5.33 \%$ drift limits were determined for Slight, Moderate, Extensive and Complete damages, respectively for mid-rise buildings. Moreover, $0.25 \%, 0.50 \%$, $1.50 \%$ and $4.00 \%$ drift limits were determined for Slight, Moderate, Extensive and Complete damages, respectively for high-rise buildings [12]. To determine damage limits and vulnerability of the structural systems, scientific guiding significance for alleviant seismic disaster risk. As a result, the authorities are prioritizing their limited resources for risk reduction in the management units [13].

\subsection{Fragility assessment theory}

An approach to estimate of structure performance and seismic risk assessment is the fragility theory. This method is a generalized arm of structural reliability that evaluates the vulnerability of a building based on ground motion intensity [14]. This expression identifies the probability of damage to meet a performance level as a function of demand on the structure [15]. The steps of fragility analysis are given and summarized in Fig.2.

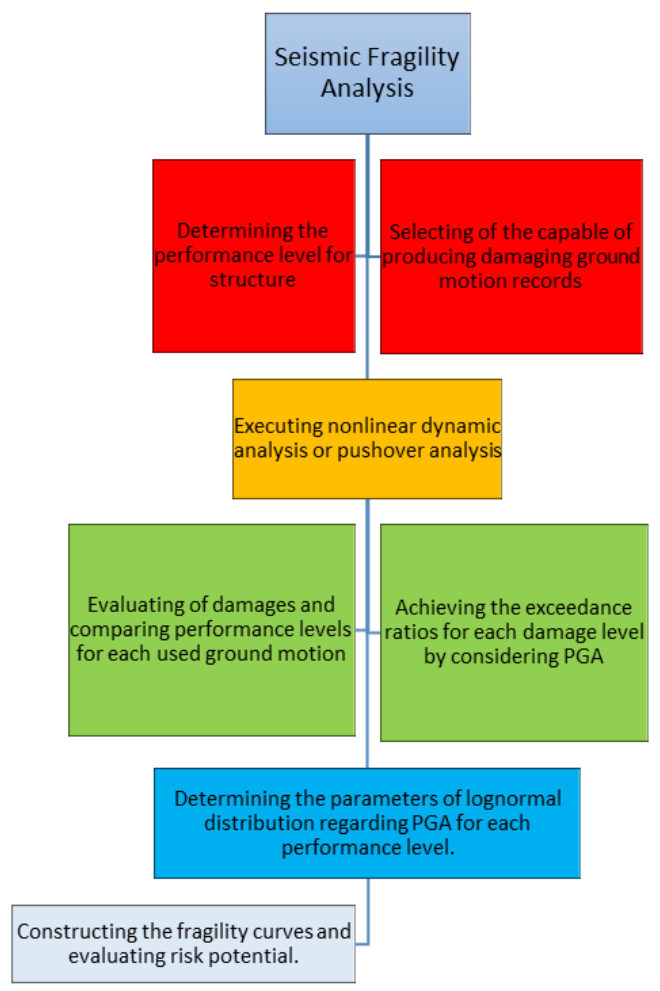

Fig 2. Flowchart of the proposed method [16] 
Researchers are interested in seismic vulnerability evaluation of the structures in recent years. Thus, studies about the seismic vulnerability of structures to reduce the earthquake disasters risk arousing curiosity. $\mathrm{Wu}$ et al. [17] investigated Seismic fragility assessment of RC frame structure designed according to modern Chinese code for seismic design of buildings. Pavel and Carale [18] evaluated seismic assessment for typical soft-storey reinforced concrete structures in Romania by performing fragility analysis. Rajeev and Tesfamariam [20] investigated seismic fragilities for reinforced concrete buildings with consideration of irregularities by using fragility analysis. Park et al. [20] applied this method and they assessed low-rise unreinforced masonry structures. Çelik and Ellingwood [21] carried out a study about seismic fragilities for non-ductile reinforced concrete frames. They used fragility curves in their paper. Ortege et al. [22] generated a vulnerability formulation for the seismic vulnerability evaluation of vernacular architecture. Kwon and Elnashai [23] evaluated the effect of material and seismic ground motion uncertainty on the seismic vulnerability curves of reinforced concrete buildings. Ellingwood et al. [24] carried out a study about fragility assessment of building structural systems in Mid-America. Rossetto et al. [25] suggested a new approach for the production of fragility curves. Their approach adapts the capacity spectrum evaluation method, and they use inelastic response spectra derived from seismic ground motions to generate fragility curves. Fragility curves can be generated through empirical [26,27], analytical [21,24-28], and heuristic [29] based methods. This study aims to propose a drift limit for TBEC2018 and to compare TEC2007 by deriving a fragility curve. On this basis, numerical analysis was performed by modeling two types of $\mathrm{RC}$ frame structures.

\section{Deriving fragility curves}

Fragility curves that permit the assessment of damage probabilities as a function of ground motion indices (PGA, PGV) or structural parameters (Sd) are evaluated as useful tools [15].
In this study, fragility curves for each member of the frame were constructed in accordance with confined concrete and reinforcement by using incremental dynamic analysis. Element damages were achieved according to unit deformation demand and categorized by considering TSC2007 [9] and TBEC2018 [10]. By this way, exceedance numbers for elements and materials, as well as exceedance ratios for each PGA of selected records, can be calculated. Analytical relationship was used during the construction of the Fragility Function. According to this approach, by using exceedance ratios and by supposing two-parameter lognormal distribution as below.

$$
\begin{aligned}
& P\left(\Delta_{D}>\delta \mid I M=i m\right)=1-\Phi\left[\frac{\operatorname{In}(\delta)-\operatorname{In}\left(\lambda_{D}\right)}{\beta_{D}}\right] \\
& \lambda_{D}=\alpha * I M^{b} \\
& f(x)=\frac{1}{\beta \sqrt{2 \pi}} \exp \left(\frac{-(x-\mu)^{2}}{2 \beta^{2}}\right) \\
& f(x)=\frac{1}{\beta x \sqrt{2 \pi}} \exp \left(\frac{-(\operatorname{In} x-\mu)^{2}}{2 \beta^{2}}\right) \text { with } x>0
\end{aligned}
$$

The probabilistic relationships between structural responses and ground motion intensity levels are given in Eq. (1). Here, $\Delta_{D}$ describes the seismic demand assumed to be lognormally distributed, while $\delta$ and im represent the specified structural demand level and ground motion intensity level, respectively. In addition to this, $\lambda_{D}$ defines the relationship between the median seismic demand. Also, $\Phi[\ldots]$ gives the standard normal probability integral. $\beta_{D}$ shows the logarithmic standard deviation of the seismic demand. In Eq. (2), $a$ and $b$ are coefficients that can be achieved from regression analyses. Normal and lognormal distributions are given in Eqs. (3) and (4), respectively. Parameters of normal and lognormal distributions are given as mean $(\mu)$, standard derivation $(\beta)$ and variable $(x)$.

\section{Numerical models and material laws}

Both models in this study were defined as fiber element models which account for plasticity. This 
plasticity is spread through the cross-section and the length of the element. The structural element in this hinge model is divided into three types of fibers: one type of fiber is used for modeling longitudinal steel reinforcing rods; the second type of fiber is used to define nonlinear behavior of confined concrete, which includes core concrete; and the third type of fiber is defined for unconfined concrete, which includes cover concrete. Also, the stress/strain diagram is determined for the nonlinearity by using constitutive laws for each fiber element like rebar, confined concrete and cover concrete, according to defined materials [3036]. Fig 3 shows typical fiber modelling for a rectangular reinforced concrete section.

\subsection{Description of numerical model}

Numerical models were generated with 5 and 7 storeys RC frame. Both of the RC frames have 5 bays and the width of the bay is $5 \mathrm{~m}$. The reason for selecting 5 and 7 story buildings is the motivation of a few studies from the literature [38, 39]. Two different concrete compressive strengths were considered C20 and C25. TSC-2018 does not allowed for lower concrete strength than $25 \mathrm{MPa}$, but the allowed minimum concrete strength was 20 $\mathrm{MPa}$ in TSC-2007. However, the basic idea is to select $20 \mathrm{MPa}$ concrete compressive strength is to simulate compressive strength degradation due to missing quality control of concrete at site. Moreover, the yield strength of rebar was considered at $420 \mathrm{MPa}$. Five story generic model, cross sections of columns, beam and steel rebar orientations are presented in Fig 4. Floor to floor height is $3.0 \mathrm{~m}$ and this value is constant for both models. The dimensions of the columns were selected as $40 \mathrm{~cm} / 40 \mathrm{~cm}$ for a 5 -story building and $50 \mathrm{~cm} / 50 \mathrm{~cm}$ for a 7 story building. Moreover, the dimensions of the beams were selected as $25 / 50$ for both of the models. The nonlinear incremental dynamic analyses were performed on the buildings as indicated in TBEC2018 [10].

For the generated buildings, the building importance coefficient is assumed to be 1.0. The boundary condition of the buildings was intended to serve as a fixed support. Also, the soil differences and damping coefficients in accordance with the soil were not considered. For IDA analyses, SeismoStruct [40] program was used which is able to simulate the inelastic structural systems response. Four Gauss integration points were selected to calculate the element forces and the stress-strain relationship for each section. In this study, while generating the numerical models, the superimposed dead load and the live load were considered as defined in the TS498 [41] for residence.

Reinforced concrete parameters related to structural elements are tabulated in Table 1.

Model-I represents $\frac{\rho}{\rho^{\prime}}=\frac{1}{2}$, Model-II represents $\frac{\rho}{\rho^{\prime}}=1$, Model-III represents $\frac{\rho}{\rho^{\prime}}=\frac{3}{2}$. Where $\rho^{\prime}$ represents the rebar area of compression reinforcement, $\rho$ represents the rebar area of tension reinforcement in beam element.
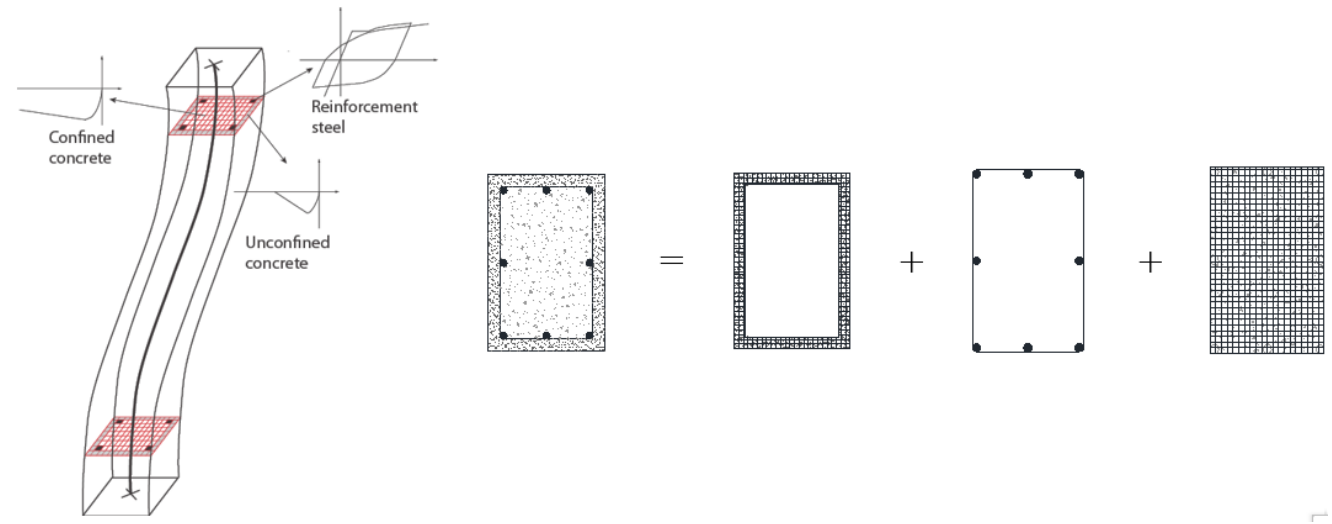

Fig 3: Typical fiber model of a RC element [37] 


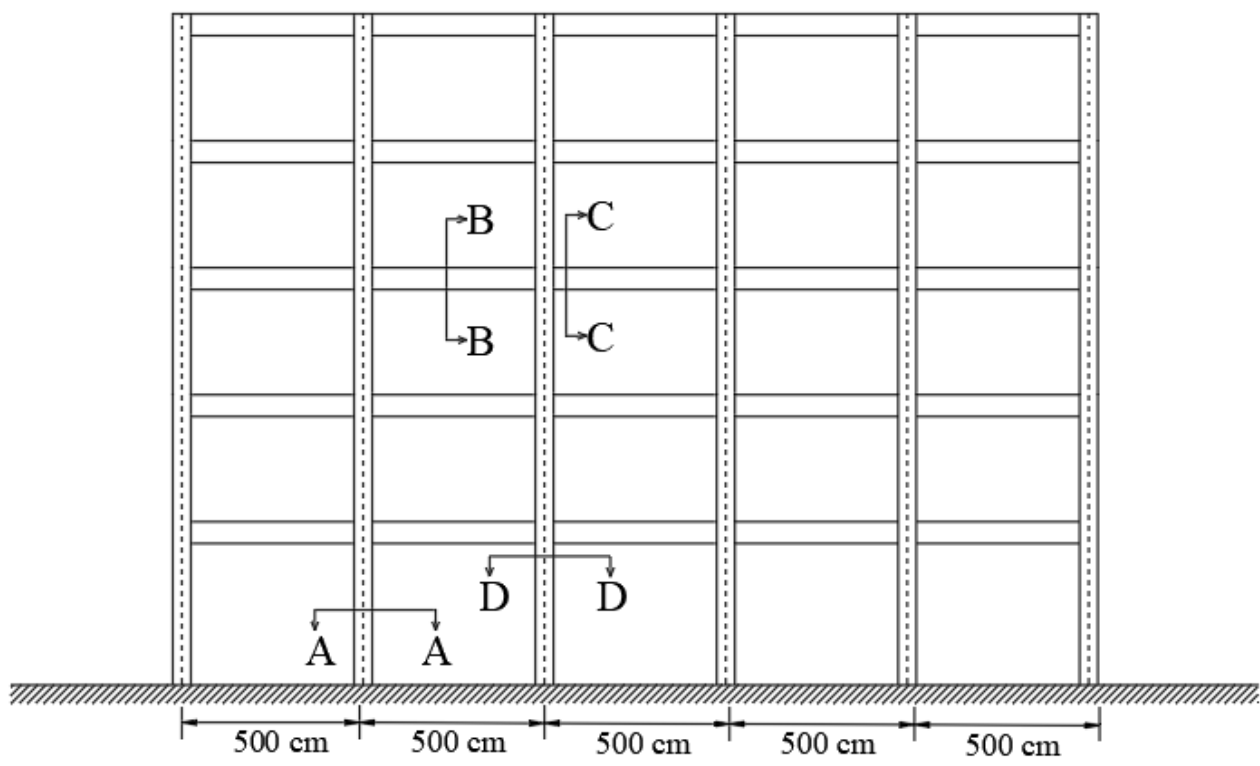

(a)

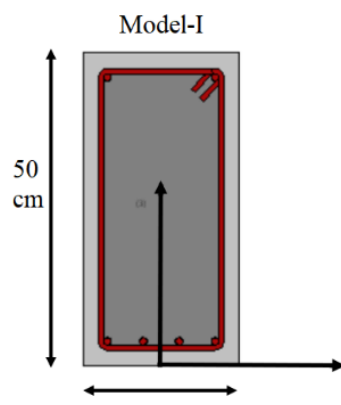

$25 \mathrm{~cm}$
Model-II

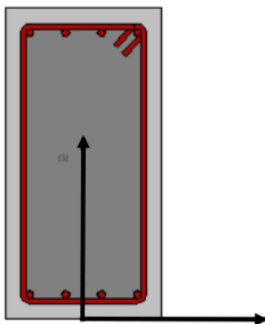

(b)
Model-III

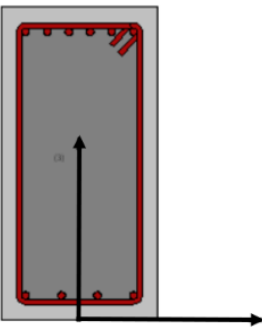

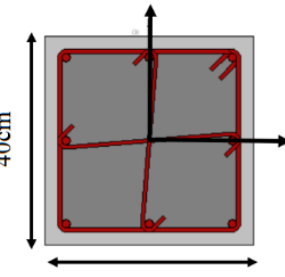

$40 \mathrm{~cm}$

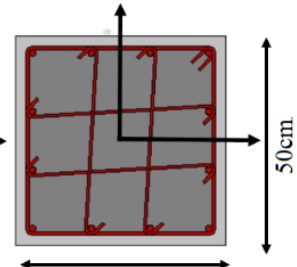

$50 \mathrm{~cm}$ (c)

Fig 4. a) Generic 5 storey model, b) Cross sections for beams, c) Cross sections for columns

Table 1. Reinforced concrete parameters related to structural elements

\begin{tabular}{|c|c|c|c|c|}
\hline Structural Elements & & $\begin{array}{l}\text { Longitudinal } \\
\text { reinforcement }\end{array}$ & Section & $\begin{array}{c}\text { Transverse reinforcement } \\
\text { spacing }(\mathrm{cm})\end{array}$ \\
\hline \multirow{2}{*}{$\begin{array}{l}\text { Column } \\
(50 / 50 \text { and } 40 / 40)\end{array}$} & $\begin{array}{l}\text { Confinement zone of } \\
\text { column }\end{array}$ & \multirow{2}{*}{$8 \varnothing 16$} & A-A & 15 \\
\hline & $\begin{array}{l}\text { Central zone of } \\
\text { column }\end{array}$ & & A-A & 15 \\
\hline $\begin{array}{l}\text { Column } \\
(50 / 50 \text { and } 40 / 40)\end{array}$ & Shear Confined Zone & $\varnothing 8$ & D-D & 7 \\
\hline \multirow{2}{*}{$\begin{array}{l}\text { Beam } \\
(25 / 50)\end{array}$} & $\begin{array}{l}\text { Confinement zone of } \\
\text { beam }\end{array}$ & $\begin{array}{c}\text { Top reinforcement } \\
4 \varnothing 12\end{array}$ & \multirow{2}{*}{ B-B } & \multirow{2}{*}{20} \\
\hline & Central zone of beam & $\begin{array}{l}\text { Bottom reinforcement } \\
4 \varnothing 12\end{array}$ & & \\
\hline Beam $(25 / 50)$ & Shear Confined Zone & $\varnothing 8$ & $\mathrm{C}-\mathrm{C}$ & 10 \\
\hline
\end{tabular}




\subsection{Adopted material models, properties and seismic records}

The bilinear elastic-plastic material model which includes kinematic strain hardening is used for the rebar. Concrete material is defined by the uniaxial confined concrete model (Fig 5). The confinement effect is calculated by using the Mander [42] model.

Indeed, TBEC 2018 suggests performing IDA with eleven seismic records. Used records were presented in Table 2 with Peak Ground Acceleration (PGA) values below. Six time history analyses were performed for each of the earthquake records ranging from $0.2 \mathrm{~g}$ to $1.2 \mathrm{~g}$ with $0.2 \mathrm{~g}$ increments. Earthquake characteristics of used seismic records can be seen in Table 2.

\section{Drift limits}

Three basic drift limits were defined; one of them is MN that represents Minimum Damage, other of them is GV that represents Safety Limits for serviceability and the final of them is GC, which represents Collapse Prevention. Drift limits in mm used in this study are based on the experimental studies of Doğan et al. [1]. These limits are tabulated in Table 3.

Based on Table 3, interstory drift ratios were defined in percent and novel drift proposals were defined and compared. Interstory drift limits and proposals are tabulated in Table 4.

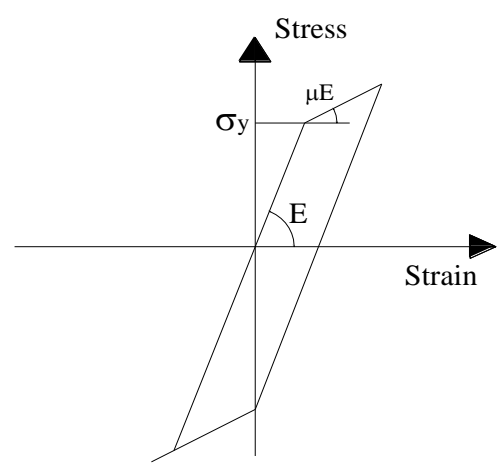

a) Reinforcing bar

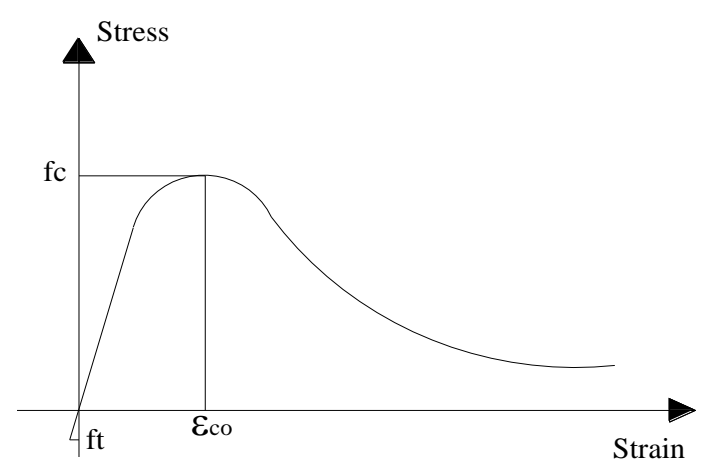

b) Concrete

Fig 5. Material models for reinforcing bar and concrete

Table 2. Selected earthquake acceleration records for dynamic analyses

\begin{tabular}{ccccccc}
\hline Number & Earthquakes & Station & Direction & Date & Magnitude & PGA (gal) \\
\hline 1 & Kocaeli & Düzce & E-W & August 17, 1999 & 7.4 & 373.76 \\
2 & Kocaeli & Sakarya & E-W & August 17, 1999 & 7.4 & 407.04 \\
3 & Düzce & Bolu & E-W & November 12, 1999 & 7.2 & 805.78 \\
4 & Düzce & Düzce & E-W & November 12, 1999 & 7.2 & 513.78 \\
5 & Van & Van-Muradiye & N-S & October 23, 2011 & 6.7 & 178.5 \\
6 & Van & Van & E-W & November 9, 2011 & 5.6 & 245.9 \\
7 & Erzincan & Erzincan & E-W & March 13, 1992 & 6.1 & 470.91 \\
8 & Bingöl & Bingöl & N-S & May 1, 2003 & 6.1 & 545.53 \\
9 & Sultandağ1 & Afyon & N-S & February 3, 2002 & 6.1 & 113.5 \\
10 & Dinar & Afton-Dinar & E-W & October 1, 1995 & 6.0 & 329.72 \\
11 & Ceyhan & Adana-Ceyhan & E-W & June 27, 1998 & 5.9 & 273.55 \\
\hline
\end{tabular}


Table 3. Drift limit ratios between TSC2007 and TBEC2018

\begin{tabular}{|c|c|c|c|}
\hline Code & Minimum damage & Safety limit & Collapse limit \\
\hline TSC2007 & $15 \mathrm{~mm}$ & $50 \mathrm{~mm}$ & $65 \mathrm{~mm}$ \\
\hline TBEC2018 & $9 \mathrm{~mm}$ & $40 \mathrm{~mm}$ & $54 \mathrm{~mm}$ \\
\hline Drift Ratio Percent $\frac{I R D_{T B E C 2018}}{I R D_{T S C 2007}}$ & $0.6 \%$ & $0.8 \%$ & $0.83 \%$ \\
\hline
\end{tabular}

Table 4. Defined drift limits and new proposals

\begin{tabular}{lcccc}
\hline \multirow{2}{*}{ Origin } & $\begin{array}{c}\text { Minimum damage } \\
(\%)\end{array}$ & $\begin{array}{c}\text { Safety limit } \\
(\%)\end{array}$ & $\begin{array}{c}\text { Extensive damage limit } \\
(\%)\end{array}$ & $\begin{array}{c}\text { Collapse limit } \\
(\%)\end{array}$ \\
\hline TSC2007 [9] & 1.0 & 3.0 & -- & 4.0 \\
Surana [14] (Mid-Rise) & 0.33 & 0.67 & 2.0 & 5.33 \\
Surana [14] (High-Rise) & 0.25 & 0.5 & 1.5 & 4.0 \\
Proposal with this study & 0.6 & 2.4 & -- & 3.3 \\
\hline
\end{tabular}

Interstory drift limit ratios were computed by using the ratios presented by [1]. Then the new limits were defined in this study to associate with TBEC2018. Generally, TBEC 2018 defined rather safer limits in terms of element-based strain levels. This new drift limits proposal is compatible with the safer philosophy of the current seismic code. A numerical application was performed to compare proposed limits with fore date seismic code in the following section and results were presented.

\section{Numerical analysis results}

PGA based fragility curves were derived by using lognormal distribution considering interstory drift limits. Fragility curves were derived by using the EasyFit program. Fragility curve comparison is issued by plotting the same model with different code. First of all, five storey building models with all tension reinforcement orientation and $20 \mathrm{MPa}$ concrete compressive strength were compared with drift limits as plotted in Fig. 6. According to fragility curves derived for five story building for all models with $20 \mathrm{MPa}$ concrete compressive strength, there is a remarkable difference between the drift limits of Model-I between the TSC2007 and the proposed limits in this study. This difference was reduced by increasing tension reinforcement ratio in the beam. Fig. 7 represents five storey building models with all tension reinforcement orientation and $25 \mathrm{MPa}$ concrete compressive strength were compared with drift limits as plotted in Fig. 7.
According to Fig. 7, there is a huge discrepancy between MN damage limit of TSC2007 and proposed limit for Model-I. This difference increases with GV drift limits. However, there are not any remarkable differences between the drift limits of GC in terms of possibility of collapse for Model-I. Increasing tension reinforcement provides rather safer settlement for the MN drift limit with proposed drift limits. This difference remains the same for GV drift limits. However, there are not any remarkable differences between the drift limits for GC drift limits for Model-II. As for Model-III, there is a constant relationship between the TSC2007 and proposed drift limits. The differences between the GV and GC drift limits are low. This discrepancy is very limited until $0.15 \mathrm{~g}$ ground shaking level. The response of seven story model was investigated by deriving fragility curves in Fig. 8 and 9. According to Fig 8, there is an obvious difference between the drift limits at all damage limits (MN, GV and GC) for Model-I. However, proposed drift limits for TBEC 2018 are rather safer for Model-II. The distinction between the drift limits is getting closer to the GC limit. The closer discrepancy for ModelII begins at a probability exceedance PGA level of more than 40\%. As for Model-III, TSC 2007 provides rather extensive differences between the $\mathrm{MN}$ and GC. This extensive difference was limited by proposed drift limits and provides rather safer limits to prevent loss of lives and properties for Model-III. 


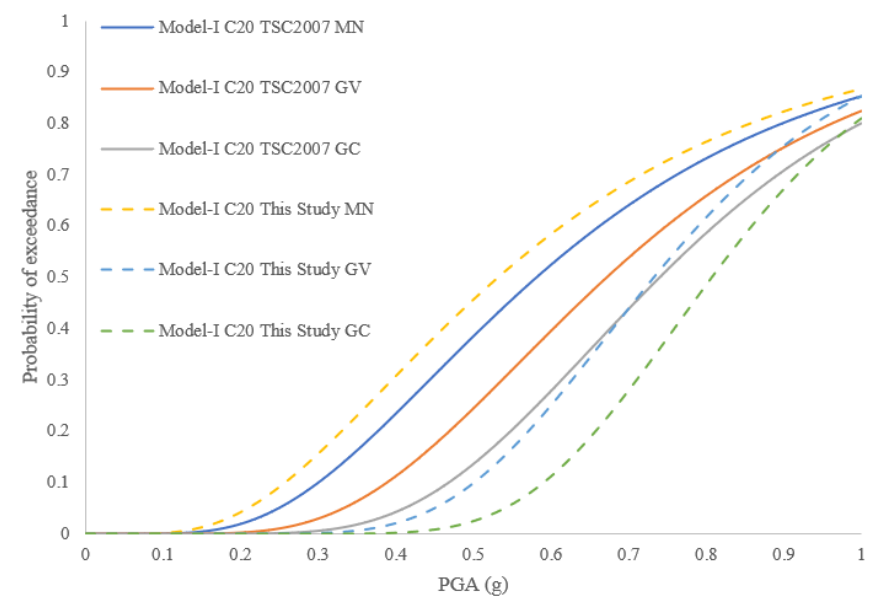

(a)

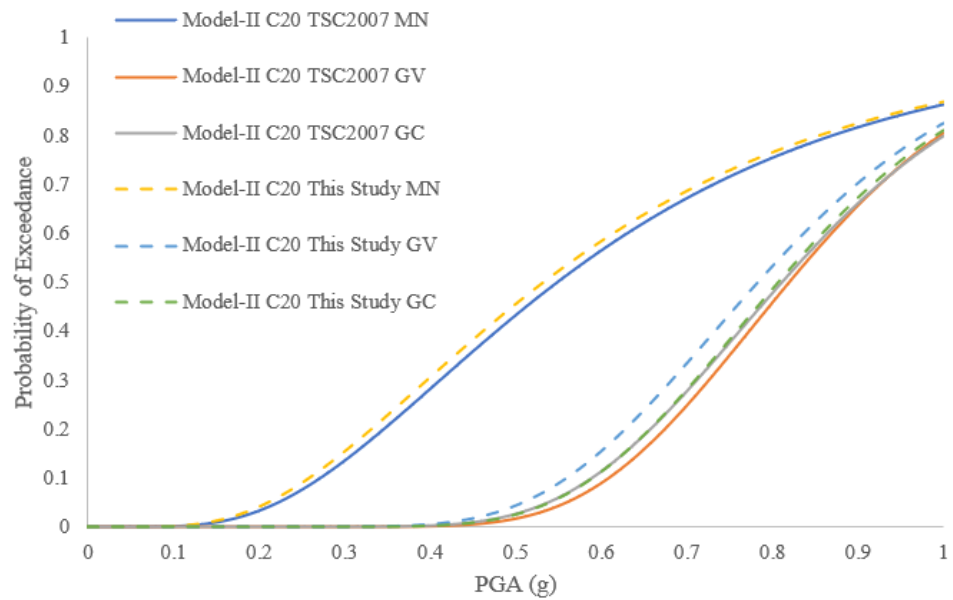

(b)

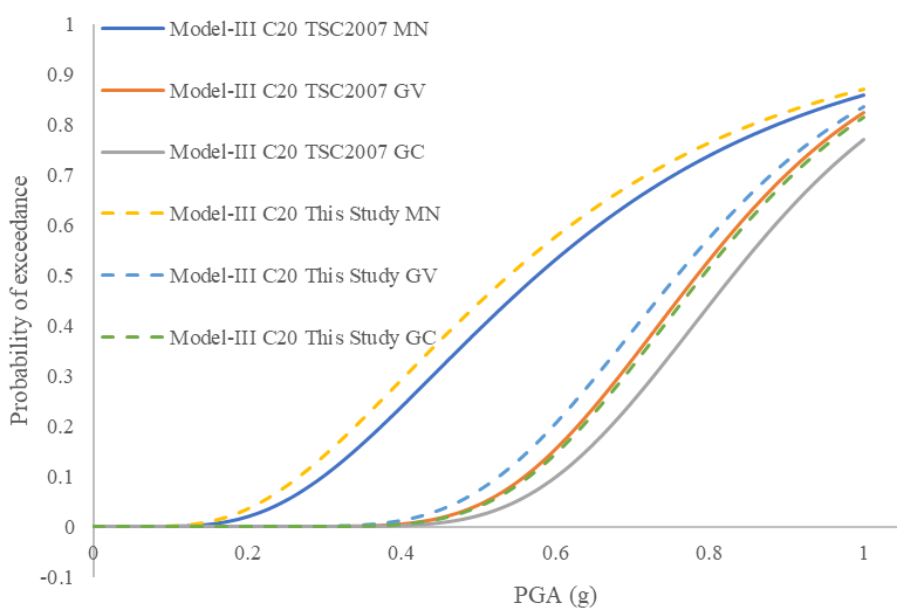

(c)

Fig. 6. Fragility curve comparison derived for five story building with $20 \mathrm{MPa}$ concrete compressive strength 


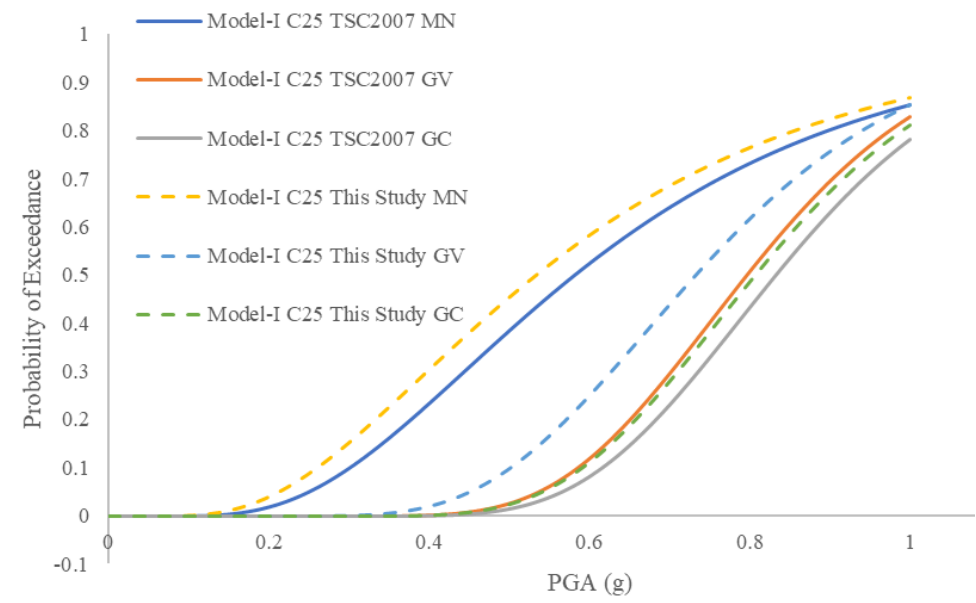

(a)

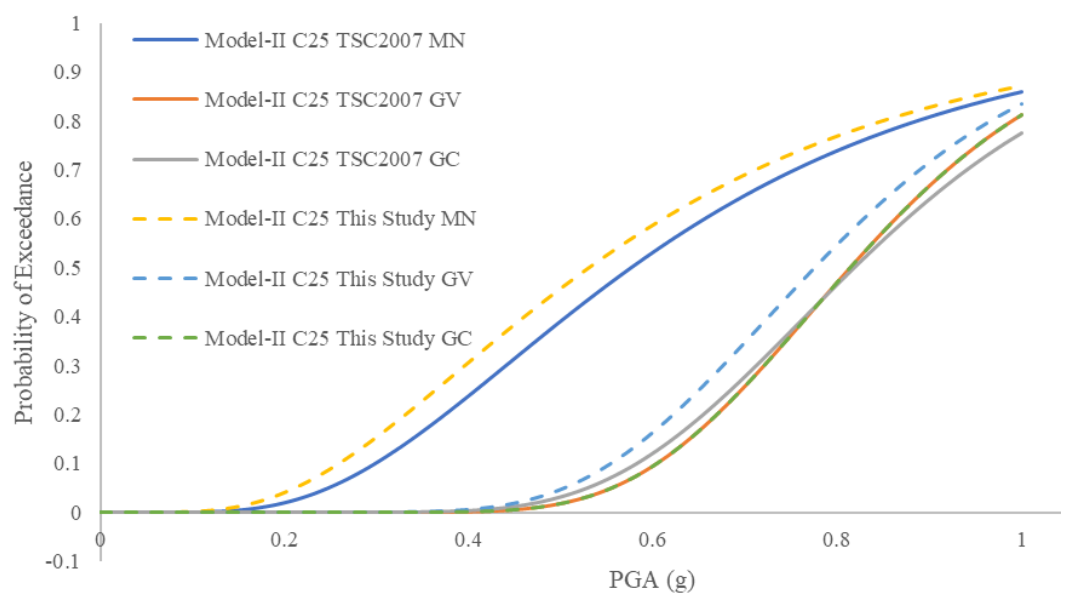

(b)

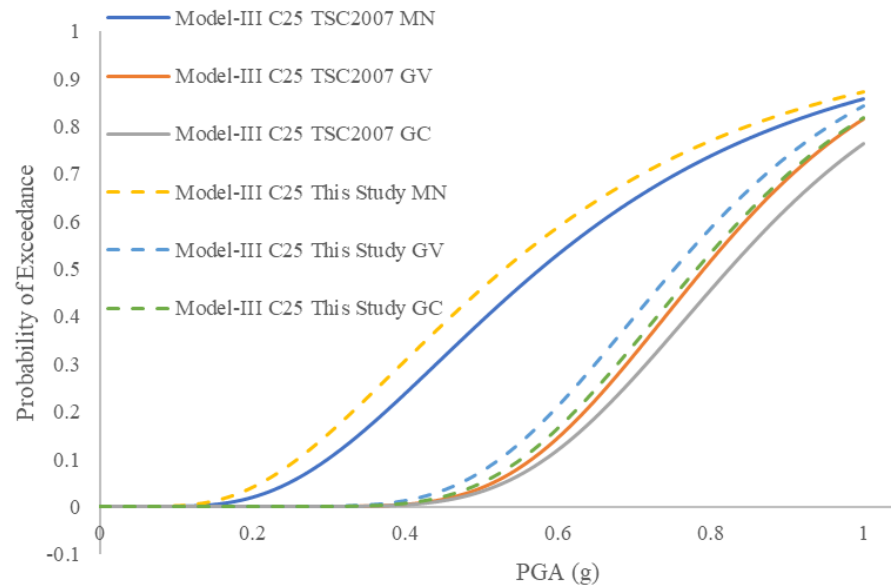

(c)

Fig. 7. Fragility curve comparison derived for five story building with $25 \mathrm{MPa}$ concrete compressive strength 


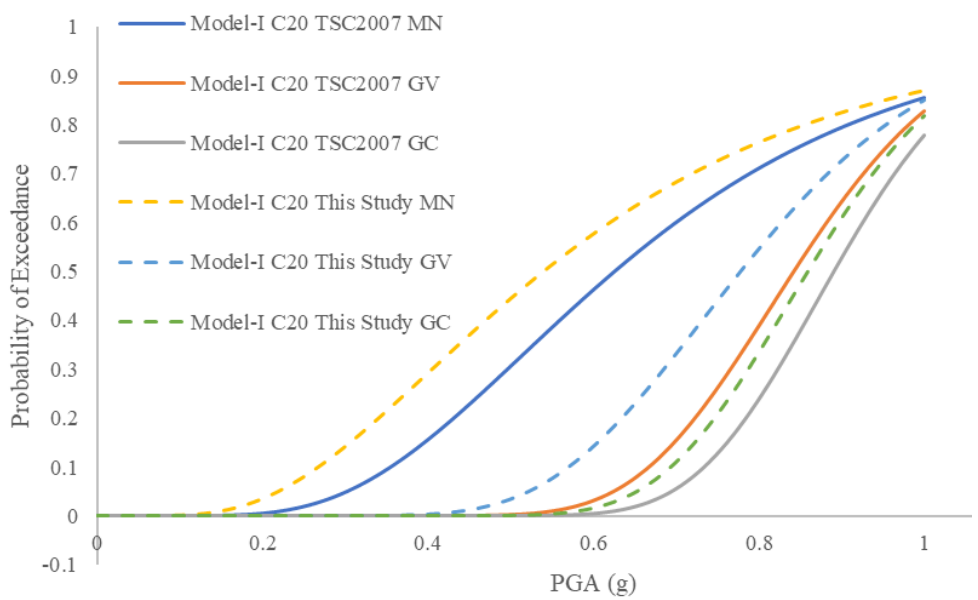

(a)

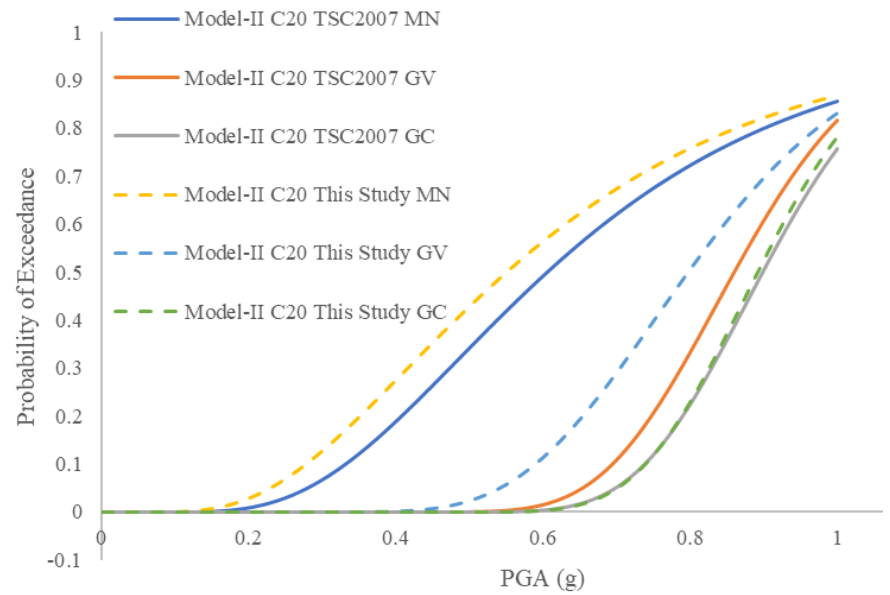

(b)

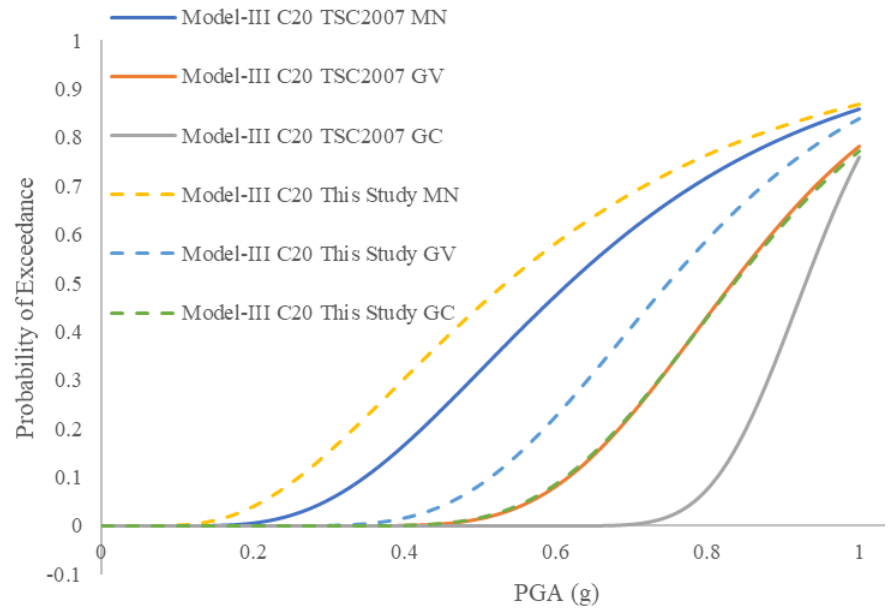

(c)

Fig. 8 Fragility curve comparison derived for seven story building with $20 \mathrm{MPa}$ concrete compressive strength 


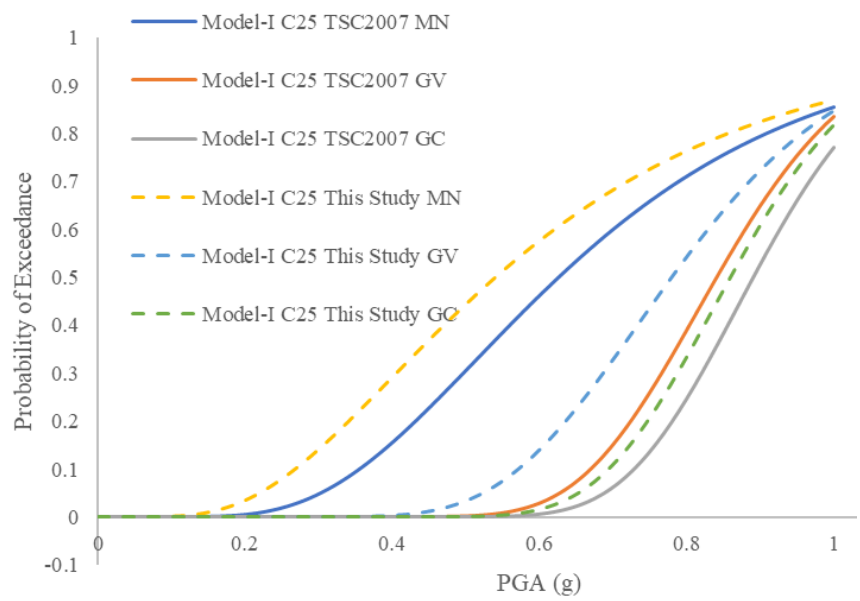

(a)

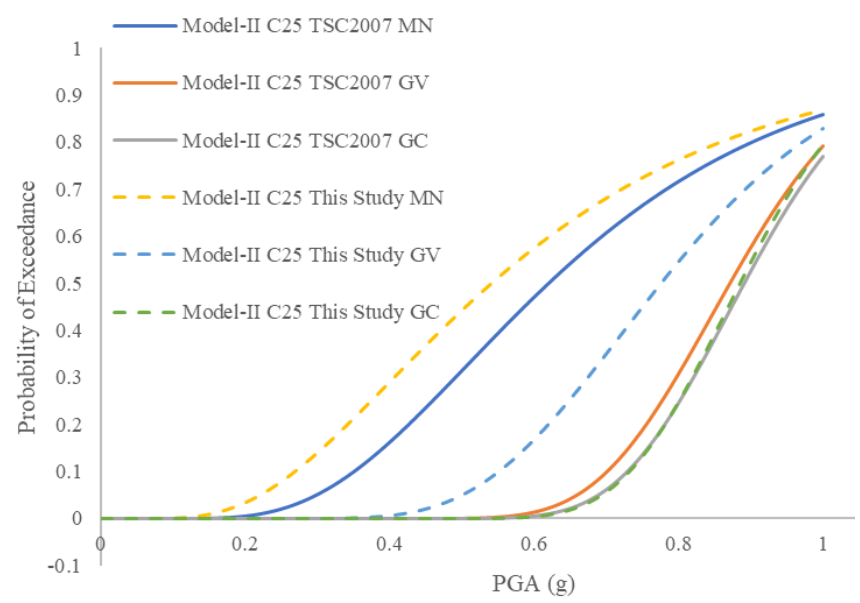

(b)

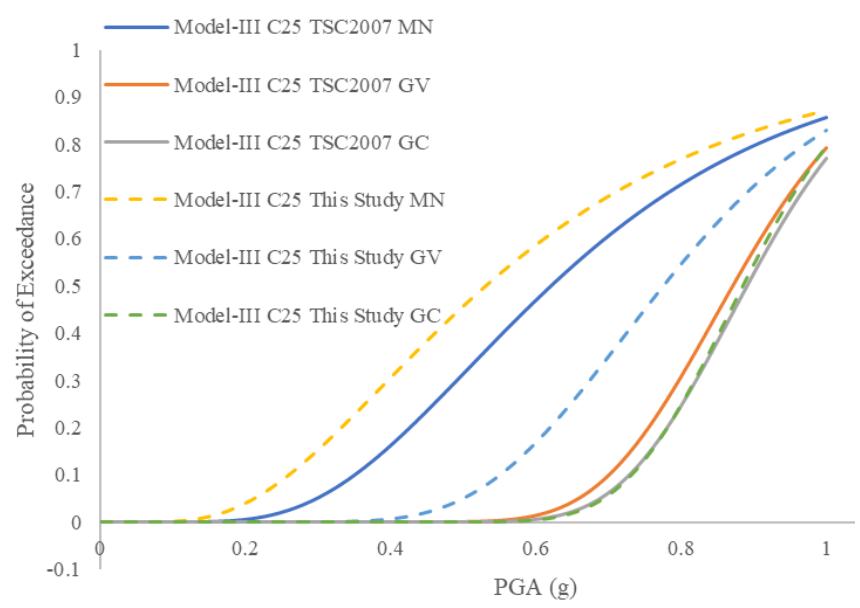

(c)

Fig. 9. Fragility curve comparison derived for seven story building with $25 \mathrm{MPa}$ concrete compressive strength 
According to Fig. 9, there is an obvious difference between the drift limits (MN, GV and GC) at Model-I for C25 concrete class. However, these differences are decreased at ultimate limits (GC) for Model-II and Model-III. In addition, proposed limits provide infinitesimal safe limits for GC level over $40 \%$ probability of exceedance. Average drift comparison of both of the buildings were plotted in Fig 10 and Fig 11, respectively.
According to Fig 10 and Fig 11, this study provides rather safer limits compared with TSC2007. The five-story model easily reached the GC (Collapse) limits with $1.0 \mathrm{~g}$ on the base of proposed limits with this study. The seven-story building model has reached the GV drift limit with $1.0 \mathrm{~g}$ ground shaking on the base proposed limit with this study. However, the drift limit occurred by $1.0 \mathrm{~g}$ ground shaking remains about the GV limit proposed by TSC2007.

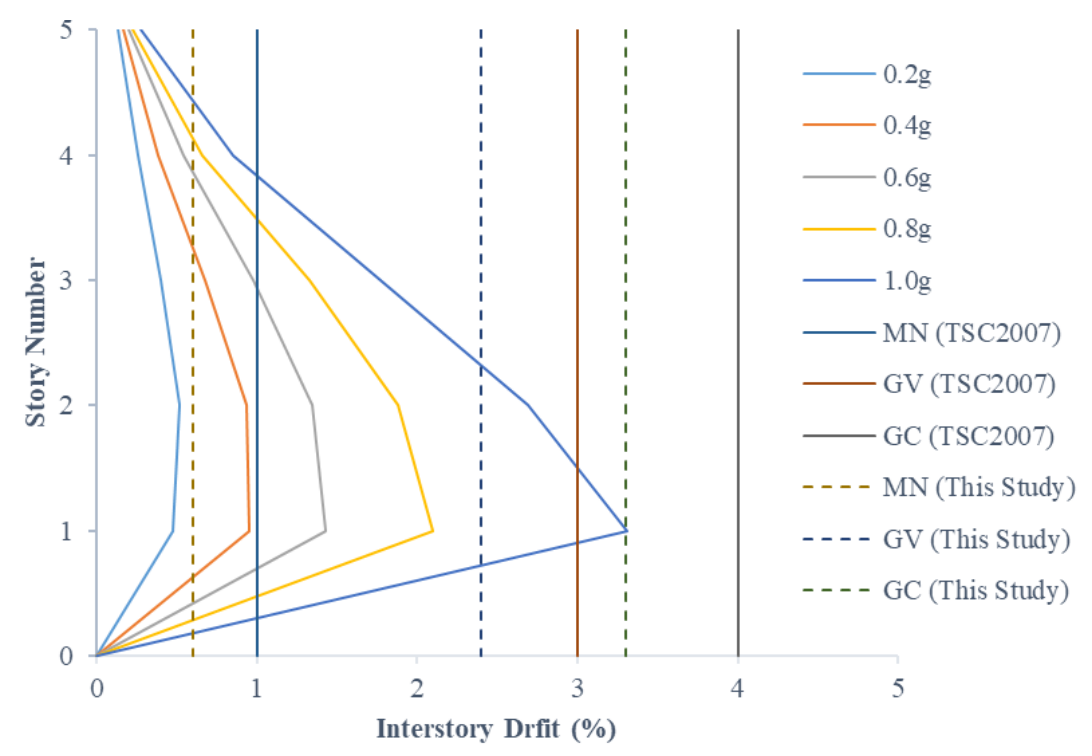

Fig. 10. Comparison of average interstory drift ratio for five story model

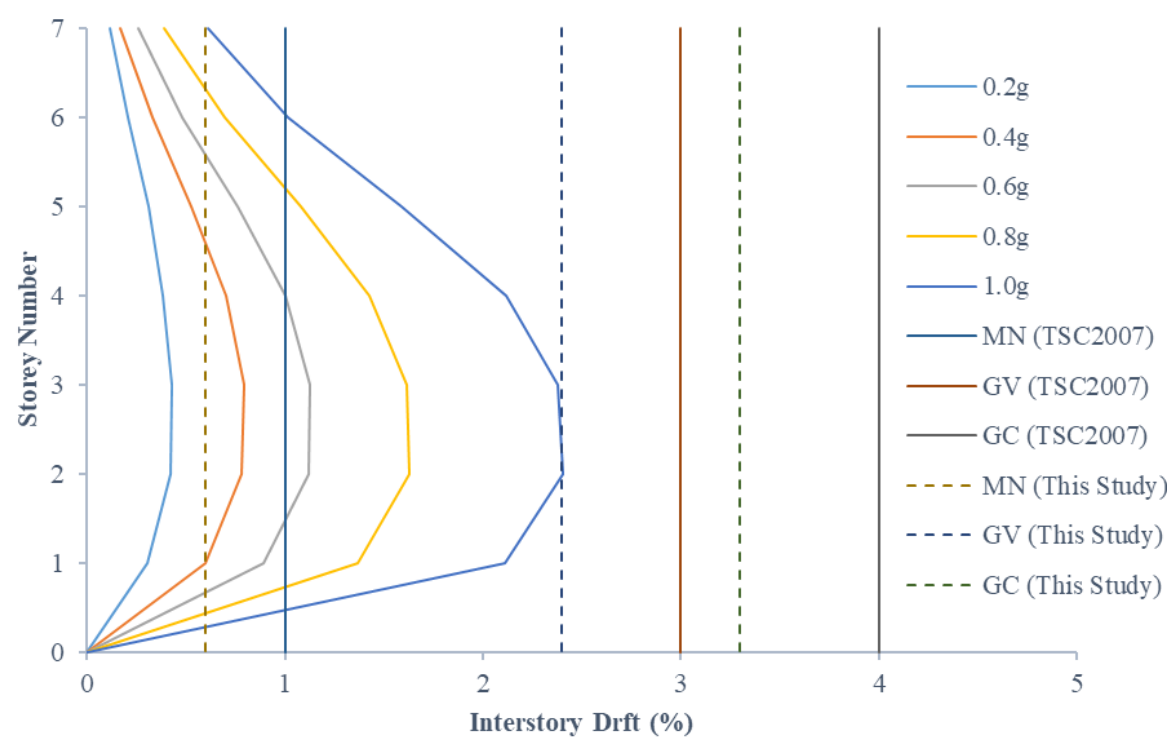

Fig. 11. Comparison of average interstory drift ratio for seven story model 


\section{Conclusion}

The basic purpose of this paper is to investigate and propose a novel inter-story drift limits for the current Turkish Seismic Code to get easy structural assessment by using software. For this aim, incremental nonlinear time history analysis was performed on modelled structures. These are two types of RC frame structures. One of them is 5 stories, the other of them is 7 stories. Two different concrete classes, C20 and C25, were considered and three tension reinforcement ratios were considered for analysis. Tension reinforcement ratios were determined by half of the compressive reinforcement, equal to compressive reinforcement and double the compressive reinforcement ratio. Incremental dynamic analyses (IDA) were performed on these buildings. After performing IDA, fragility curves were plotted and compared. The following remarks were drawn:

- Proposed novel interstory drift limits are $0.6 \%$, $2.4 \%$ and $3.3 \%$ respectively for $\mathrm{MN}, \mathrm{GV}$ and GC.

- Proposed interstory drift limits provide practitioners to be kept safe while performing structural assessment at $40 \%, 20 \%$ and $17.5 \%$, respectively for MN, GV and GC limits.

- Even if, plotted analysis results remain on the safe side on the basis of proposed drift limits with this study, derived fragility curves represent that proposed limits have a remarkable difference between the TSC2007 limits when the structural system has poor concrete at $\mathrm{MN}$ and $\mathrm{GV}$ limits. This result is correct for five and seven story models.

- According to fragility curves, it is seen that the damage probability for TBEC2018 is higher than TSC2007. It is visible at all damage levels.

- To determine the vulnerability of a structural system, a fragility curve is preferable to an interstory drift graph.

\section{Declaration of conflicting interests}

The author(s) declared no potential conflicts of interest with respect to the research, authorship, and/or publication of this article.

\section{References}

[1] Dogan G, Arslan MH, Baykan OK (2020) Determination of damage levels of RC columns with a smart system-oriented method. Bulletin of Earthquake Engineering 18:3223-3245.

[2] Yön B, Onat O (2018) 3 Aralık 2015 Bingöl-Kiğ depreminin Tunceli ilindeki yığma yapılara etkisinin değerlendirilmesi. Dicle Üniversitesi Mühendislik Fakültesi Mühendislik Dergisi, 9(1): 375-385.

[3] Yön B, Onat O, Öncü ME (2019) Earthquake damage to nonstructural elements of reinforced concrete buildings during 2011 Van seismic sequence. Journal of Performance of Constructed Facilities 33(6): 04019075.

[4] YönB, Onat O, Öncü ME, Karaşin A (2020) Failures of masonry dwelling triggered by East Anatolian Fault earthquakes in Turkey. Soil Dynamics and Earthquake Engineering 133: 106126.

[5] Sayın E, Yön B, Onat O, Gör M, Öncü ME, Tunç ET, Calayır Y (2021) 24 January 2020 SivriceElazığ, Turkey earthquake: geotechnical evaluation and performance of structures. Bulletin of Earthquake Engineering 19(2): 657-684.

[6] Yön B. Sayın E, Onat O. Earthquakes and structural damages. In: Zouaghi T. (ed) EarthquakesTectonics, Hazard and Risk Mitigation, In-Tech Open, 2017, pp 319-339.

[7] Atmaca B, Demir S, Günaydın M, Altunışık AC, Hüsem M, Ateş Ş, Angın Z (2020) Lessons learned from the past earthquakes on building performance in Turkey. Journal of Structural Engineering \& Applied Mechanics 3(2): 61-84.

[8] Atmaca B, Demir S, Günaydin M, Altunış1k AC, Hüsem M, Ateş Ş, Angın Z (2020) Field investigation on the performance of mosques and minarets during the Elazig-Sivrice Earthquake. Journal of Performance of Constructed Facilities, 34(6): 04020120.

[9] Turkish Seismic Code TSC-2007: Specification for buildings to be built in earthquake regions. Turkish Standards Institute, Ankara, 2007.

[10] Turkish Building Earthquake Code (TBEC): Ministry of public works and settlement. Ankara, Turkey, 2018.

[11] Aksoylu C, Mobark A, Arslan MH, Erkan İH (2020) A comparative study on ASCE 7-16, TBEC2018 and TEC-2007 for reinforced concrete buildings. Revista de la Construcción 19(2): 282305. 
[12] Surana M (2020) Seismic fragility curves using pulse-like and spectrally equivalent ground-motion records. Earthquakes and Structures 19(2): 79-90.

[13] Zhou J, Li S, Nie G, Fan X, Deng Y, Xia C (2020) Research on seismic vulnerability of buildings and seismic disaster risk: A case study in Yancheng, China. International Journal of Disaster Risk Reduction 45: 101477.

[14] Zhang JH, Hu SD (2005) State of the art of bridge seismic vulnerability analysis research. Structural Engineers 21(5): 76-80.

[15] Senel SM, Kayhan AH (2010) Fragility based damage assessment in existing precast industrial buildings: A case study for Turkey. Structural Engineering \& Mechanics 11(1): 39-60.

[16] Yon B (2020) Seismic vulnerability assessment of RC buildings according to the 2007 and 2018 Turkish seismic codes. Earthquakes and Structures 18(6): 709-718.

[17] Wu D, Tesfamariam S, Stiemer SF, Qin D (2012) Seismic fragility assessment of RC frame structure designed according to modern Chinese code for seismic design of buildings. Earthquake Engineering and Engineering Vibration 11(3): 331342.

[18] Pavel F, Carale G (2019) Seismic assessment for typical soft-storey reinforced concrete structures in Bucharest, Romania. International Journal of Disaster Risk Reduction 41: 101332.

[19] Rajeev P, Tesfamariam S (2012) Seismic fragilities for reinforced concrete buildings with consideration of irregularities. Structural Safety 39: $1-13$.

[20] Park J, Towashiraporn P, Craig JI, Goodno BJ (2009) Seismic fragility analysis of low-rise unreinforced masonry structures. Engineering Structures 31(1): 125-137.

[21] Celik OC, Ellingwood BR (2010) Seismic fragilities for non-ductile reinforced concrete frames-Role of aleatoric and epistemic uncertainties. Structural Safety 32(1): 1-12.

[22] Ortega J, Vasconcelos G, Rodrigues H, Correia M (2019) A vulnerability index formulation for the seismic vulnerability assessment of vernacular architecture. Engineering Structures 197: 109381.

[23] Kwon OS, Elnashai A (2006) The effect of material and ground motion uncertainty on the seismic vulnerability curves of RC structure. Engineering structures 28(2): 289-303.

[24] Ellingwood BR, Celik OC, Kinali K (2007) Fragility assessment of building structural systems in Mid-America. Earthquake Engineering \& Structural Dynamics 36(13): 1935-1952.

[25] Rossetto T, Gehl P, Minas S, Galasso C, Duffour P, Douglas J, Cook O (2016) FRACAS: A capacity spectrum approach for seismic fragility assessment including record-to-record variability. Engineering Structures 125: 337-348.

[26] Rossetto T, Elnashai A (2003) Derivation of vulnerability functions for European-type RC structures based on observational data. Engineering structures 25(10): 1241-1263.

[27] Shinozuka M, Feng MQ, Lee J, Naganuma T (2000) Statistical analysis of fragility curves. Journal of Engineering Mechanics 126(12): 12241231.

[28] Rossetto T, Elnashai A (2005) A new analytical procedure for the derivation of displacement-based vulnerability curves for populations of RC structures. Engineering Structures 27(3): 397-409.

[29] ATC: Earthquake Damage Evaluation Data for California, ATC-13 Report, Applied Technology Council, Redwood City, California, 1985.

[30] Yön B, Calayır Y (2015) The soil effect on the seismic behaviour of reinforced concrete buildings. Earthquakes and Structures 8(1): 133-152.

[31] Yön B, Öncü ME, Calayır Y (2015) Effects of seismic zones and local soil conditions on response of RC buildings. Građevinar 67(06): 585-596.

[32] Yön B, Calayır Y (2014) Effects of confinement reinforcement and concrete strength on nonlinear behaviour of RC buildings. Computers and Concrete 14(3): 279-297.

[33] Doğangün A, Yön B, Onat O, Öncü ME, Sağıroğlu S (2021) Seismicity of East Anatolian of Turkey and failures of infill walls induced by major earthquakes. Journal of Earthquake and Tsunami, 2150017.

[34] Onat O, Lourenco PB, Kocak A (2015) Experimental and numerical analysis of $\mathrm{RC}$ structure with two leaf cavity walls subjected to shake table. Structural Engineering \& Mechanics 55(5): 1037-1055.

[35] Onat O, Lourenco PB, Kocak A (2016) Nonlinear analysis of RC structure with massive infill wall exposed to shake table. Earthquake and Structures 10(4): 811-828.

[36] Onat O, Yön B, Calayır Y (2018) Seismic assessment of existing $\mathrm{RC}$ buildings before and after shear-wall retrofitting. Građevinar 70(08): 703-712. 
[37] Rodrigues H. Biaxial seismic behaviour of reinforced concrete columns, $\mathrm{PhD}$ Thesis, Universidade de Aveiro, Portugal. 2012.

[38] Arslan G, Borekci M, Sahin B, Denizer MI, Duman KS (2018) Performance evaluation of in-plan irregular RC frame buildings based on Turkish seismic code. International Journal of Civil Engineering 16(3): 323-333.

[39] Shafaei H, Naderpour H (2021) Collapse capacity of ordinary RC moment frames considering mainshock-aftershock effects. Journal of Earthquake Engineering DOI: 10.1080/13632469. 2021.1871679 .
[40] SeismoStruct v7: A computer program developed for the accurate analytical assessment of structures, subjected to earthquake strong motion. Available online: www.seismosoft.com

[41] TS498: The calculation values of loads used in designing structural elements. Turkish Standard Institute, Ankara, Turkey, 1997.

[42] Mander JB, Priestley, MJN, Park R (1988) Theoretical stress-strain model for confined concrete, ASCE Journal of Structural Engineering 114(8): 1804-1826. 